\title{
Study of Restriction of Cultural Context in English Translation
}

\author{
Jin $\mathrm{Wu}^{1}$, Lei $\mathrm{Xu}{ }^{2}$ \\ ${ }^{1}$ Jiangxi Institute of Economic Administrators, Nanchang, Jiangxi, 330038 \\ 54892713@163.com
}

Keywords: Cultural Context; English Translation; Constraints

\begin{abstract}
One of the important results of researches linguistics is made of context translation plays a vital role in the Context of. As an important stylistic, the English translation is bound to be constrained and influence of context, and the context of research and translation of research has even cultural context to a new level of theory.
\end{abstract}

\section{Introduction}

With the continuous development of economic globalization and international economic and trade exchanges, and foreign exchanges become more frequent, the English position in international economic activities more and more prominent, so the English translation is very important. In international activities, a powerful tool for English as a foreign exchange translation smoothly, certainly it will be the interlocutors cultural influences and constraints. Therefore, body language and stylistic analysis for the lead, investigate the effect of cultural context of translation has important significance.

Cultural context is the whole language system environment and its entire language system plays a vital role. Since the concept of cultural context proposed by British anthropologist Bronislaw Malinowski, many scholars from different angles and dimensions of the cultural context of a lot of research. Cultural context is not only a part of the culture, but also a cultural image. It includes the use of language in social and cultural background, historical and cultural traditions, ways of thinking, values, love to know and social psychology. Dependent on the presence of cultural and language presence, deeply influenced by culture, therefore, it will inevitably be affected by local social culture. As cross-cultural communication translation activities, the impact of context can not be ignored even very important. The translation process is a process of understanding and re-expression of the pure understanding is different is that this process requires both faithfully express the details of the original, but also so that the original author's intent in the translation process can be retained, the translation requirements "faithfulness, expressiveness and elegance" "Elegance" is difficult to achieve, and this is often part of the cultural context and the relationship is relatively large.

Our linguist Mr. Luo Changpei said: "Language is the crystallization of a national culture, the culture of this nation in the past relied on to spread, it relied on the future of culture to promote." In today's world, science and technology advances, the rapid dissemination of information, cross-cultural communication increasingly widespread, translation as intercultural communication bridge is playing an increasingly important role. Translation is not only the language of conversion activity, it is the exchange and transplantation activities in different cultures. With China's reform and opening up, China's products continue to enter the international market, Chinese and foreign cultural exchanges become more frequent. In this situation, the translation work has become increasingly important. Translators not only bear the introduction of information and culture outside the domain of technical tasks, but also bear the spread of Chinese culture to the world mission.

\section{The Concept of Cultural Context}

Since Frege in 1884 proposed the concept of "context principle" in "Grundlagen" in its contextual theory of growing concern multidisciplinary and has made rapid progress. Especially the modern, contextual issues surrounding Western anthropologists, linguists, philosophers, and even 
artificial intelligence scientists have carried out long-term exploration, making it develop into an independent interdisciplinary learning context. "Each language has its own history and culture community, customs, social conventions, ways of thinking, values which reflect the particular characteristics of the way speech community and factors that constitute said -. Cultural Context"

Hall in his 1976 book "Beyond Culture," a book put forward their views, "culture is contextual," and will be divided into high and low cultural context. Different cultures have different communicative environment dependence, the main difference between the two and features are as follows: First, high context coding of context dependence, a lot of semantic hidden in context, without pointing; and Whispers Habitat for encoding information is fully reflected by the speech, almost unaffected by context. Then, high-context culture is often affected by context, the significance of information for more rely on the subjective feelings of the listener, is a "can only be felt, not explained," the exchange; low context cultures tend to rely on through language biography's intention, which was significantly more direct communication. Finally, there are significant differences in the level of the members of the cultural context of self-disclosure as well. Thus, in the context of high cultural process, the cultural context has become a very important translation factor.

Cultural context is important linguistics study of language use and function. It refers to the use of language in social and cultural background, a common understanding of history and tradition, social psychology, values, ways of thinking, as well as people of nature, human society and the human mind. It was first used by the British anthropologist Malinowski raised. In the study of language, he said: "Context is the sole factor in determining semantics, from the context, namely the absence of semantics." He put context into two categories: one is the cultural context; the other is the scenario language territory. The latter refers to what actually happened speaker involved, namely the actual language environment occurred. Cultural context is to determine the environment within the meaning of the language, it is composed of numerous specific situational context constituted, while at the same time situational context and cultural context dominated by the two complement each other. In other words, cultural context including the then politics, history, philosophy, science, folk and other ideological and cultural awareness, including contemporary writers and their works. So the original cultural context to understand the most important prerequisite is ready translation.

\section{Social and Cultural Background Influence on Translation.}

Because culture is defined to be within a certain range of social or popular set of social values and beliefs, it is the way of all activities throughout the life of a society, but also a nation. The language is an important part of human activity, and therefore inextricably linked with culture, and influenced by culture.

In the process of teaching students, but to teach students some of the relevant cultural knowledge in order to enable students to really use the language. For example, the Chinese people in a very long period of time, always fill his belly as the highest goal, therefore, to meet the "you eat it?" To say hello to each other, and was greeting people, whether it is eaten or not eaten, will give a response, and do not think the other side would like to invite you to dinner. But in English, the greetings were more to the "Hello" or "How are you" kind of thing, mainly in Western culture and the initiative to ask whether the other meals, will make people think you have to ask him to dinner misunderstanding. They greeted more to have a spiritual meaning greeting.

In the process of learning English, if not pay attention to cultural influences, and sometimes there will be the previous case. China is said to have a person to play the United States, unfortunately, the way the car in a car accident, the car overturned into the ditch mountain, there are good people see on the police. Police arrived, on the front of the ravine shouted: "How are you?" The man although very painful, but still loudly replied: "! I'm fine, thank you" after listening to the police, turned away, and he is also due to injured too heavy and death. Perhaps this is a model of cultural background differences bar. 


\section{Environmental and Historical Geographical Differences on Translation}

Britain is a country surrounded by the sea, and attaches great importance to the maritime industry, and there are many sea-related phrases. For example: Any port ina storm, literally storm, do not select the port. In fact, we often use "Huangbuzelu" to express the same meaning. English Tell that to the marines used to represent the meaning of nonsense, we used the same meanings as fantasy. There are similar: the same is a spendthrift, English is spend money likewater, Chinese are big spenders, which once again shows the UK island, surrounded by a lot of water. Representing the arrival of spring, a symbol of spring and warm meaning when, When the wind is in the east, it's goodfor neither man nor beast, described the British do not like the wind, because for them, the land east from Europe, relatively cold. Thus, for Britons, westerly Primula. The same Primula, because of China's south-east is the ocean, the wind blowing from the ocean is gentle, so Chinese people generally like wind or southerly wind of spring is often used.

Impact of historical factors should also be fully taken into account. In English, "tomeet one's Waterloo" originated in Napoleon at Waterloo in Belgium suffered a crushing defeat of his life. Although the two things are not the same people and places, but can clearly fiasco of expression. Expressed helpless, British usually "my god", primarily because they are more Christian West, God is their master. And because more people believe in Buddhism, it is more with "My God," or "My God," to express the inner despair and helplessness.

This shows the inside of the slang English translation pay more attention to the impact of geography, history and culture. Five thousand years of Chinese culture in the development process, accumulated a lot of idioms, such as: the Moon, belie, deceiving, and other idioms Destructive Enthusiasm, if not understand the deeper meaning, but literally translated, it will only make more foreigners do not understand.

\section{Impact Way of Thinking and Values on Translation}

Cultural differences also show expression in some fashion. British and imaginative thinking, feeling rough, so English "I love you" almost became their mantra. Meet in public hugging and kissing is one of the basic etiquette. The Chinese people's way of thinking leads to the expression of their feelings more subtle, more nuanced performance, saying "I love you" and a kiss of love between men and women is almost a patent, but most of them still can not be performed in public, or is indecent.

Western values are more personal values first, they were trained by this independent spirit nurtured in the process of doing things they hardly linked with their families and units, they are more respected individual heroism. Chinese people have been taught is: what they are doing to consider the family unit, the state and the nation, often for the first collective honor, after personal interests, even sacrificing, my big achievement. In our minds, the athlete should glory for the country, the soldiers should be ready to die for your country, these are unalterable.

Dog and dog in both English and Chinese middle generation is the same kind of animal, the literal meaning is similar, but the cultural significance is a big difference. Chinese people have mentioned the dog when almost no good word, for example: Hupenggouyou, henchman, bitch, snob, Gouzhangrenshi etc., in such cultural background on the formation of everyone consensus. As well as with "Gounahaozai" to rebuke someone should do something. Seen in the Chinese culture, the dog is a derogatory term, that we love the dog is far less than the British and American people. Due to the different values, so that Americans dog very valued, in their view, very loyal dog is man's best friend, so only: a lucky dog (lucky), love me love my dog (he is in love), so Britain has stray dog living at home, they'll take care of it well. In their view, is an inhumane practice, it will be around despised. 


\section{Conclusion}

In summary, in the translation process, in addition to attention to each other than words and grammar, the language must be where the culture, geography, history and values of the country have more in-depth understanding, so as to effectively avoid misunderstandings and translation misinterpreted. Therefore, it requires careful analysis of various factors translator behind the sentence, so that on the basis of the original faithfully reflect the translation of implication, the effective realization of communication and exchange the two cultures.

\section{References}

[1] Zhang Peiji. Chinese Translation Guide. Shanghai: Shanghai Foreign Language Education Press, 2003.

[2] Zhu Yaocun. Cultural Differences and Translation. Chinese Translation, 1997 (4).

[3] Hu Wenzhong. Sino-British Cultural Practices Compare. Beijing: Foreign Language Teaching and Research Press, 2001.

[4] Party Kim Hak. Translation Depend Contradictory Culture. Chinese Translation, 1997 (1).

[5] Huang Xiaoyan. The Role of Context on English Chinese Translation. Harbin Vocational and Technical College, 2012 (3). 